\title{
Merging populations
}

\section{A look at marriages with foreign-born persons in European countries}

\begin{abstract}
Mixed marriages have long been considered important indicators of the social integration of immigrants, as well as potential factors of social and cultural change. By using data from two $E U$ surveys, the percentage of persons in mixed marriage is estimated in 30 European countries over recent years. Across Europe, for the period 2008-10, on average one in 12 married persons was in a mixed marriage.

Mixed unions can be defined according to various characteristics such as ethnicity, religion or country of birth. In this report, mixed marriages are defined as those in which one partner is native-born and the other was born abroad. Thus, marriages between
\end{abstract}

foreign-born persons from different countries are not considered as mixed here. Further, by focussing on marriages, unmarried partnerships are not included.

Figure 1 shows wide differences in the prevalence of mixed marriages across Europe. The range is from about one mixed married couple out of five in Switzerland and Latvia, to almost none in Romania. For most countries, there is an increase over time, while the geographic distribution suggests a NorthWest/South-East divide, with some exceptions such as the Baltic countries. In general, countries in which immigration is a more recent phenomenon or is less relevant show lower values.

Figure 1: averages for 2005-07 and 2008-10 of the percentage of mixed couples on total married couples by country (countries sorted by descending order on the period 2008-10)

$25 \%$

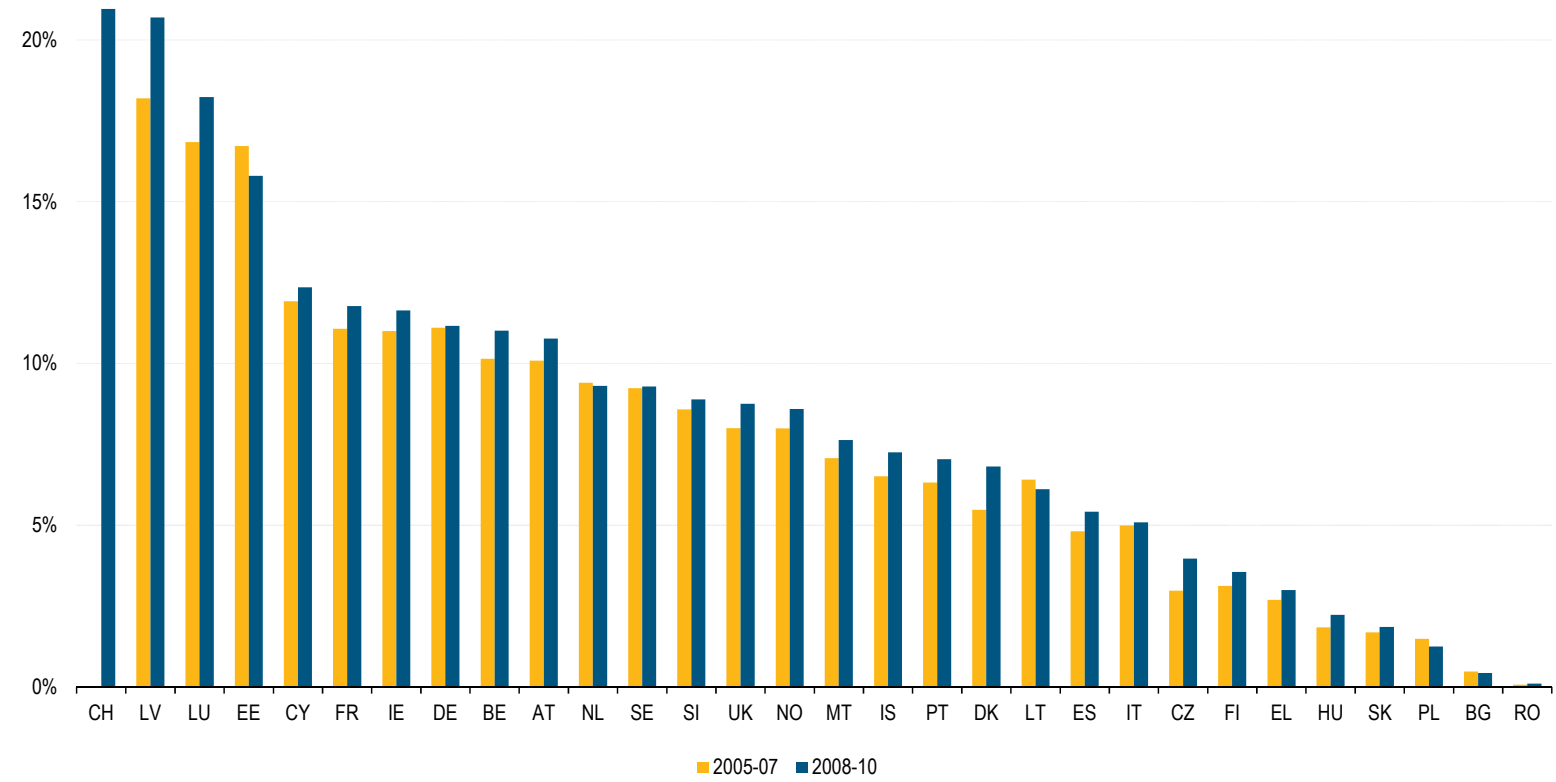

Source: See methodological notes 
Marriage patterns generally depend on individual preferences, opportunities in the marriage market and the influence of third parties. In the case of foreignborn persons, the opportunities for finding a partner of the same group are also linked to the size of the community, as well as to the proportion of potential opposite-sex partners within the group.

These contextual factors are more relevant for explaining the occurrence of new marriages than for the number of existing unions at a given moment, because the latter group includes older marriages which may have occurred at a time when conditions were different. Nevertheless, looking at the proportion within subgroups of the populations (e.g. native-born men) provides additional insights about the prevalence of mixed marriages (see Table 1). The proportions of mixed marriages are much higher among foreign-born married persons than among those born in the country.
Where the relative size of the foreign-born community is more significant, the possibility of a native-born person meeting a foreign-born partner increases, and so may their percentage of mixed marriages. A foreignborn person may have less choice if they seek a partner from the same group and mixed marriages are thus a more frequent outcome. However, several other factors influence the choice of marriage partner, such as socioeconomic and cultural characteristics of the potential partner, residential segregation or social norms. Further, descendants of foreign background may be included in the native-born groups, and foreign-born persons whose marriage occurred abroad prior to immigration are also included in the population of reference.

For a large majority of the countries, a higher percentage of foreign-born women are in mixed marriages than foreign-born men. For native groups, the reverse applies.

Table 1: average 2008-10 of the percentage of persons in mixed marriage by country and population of reference

\begin{tabular}{|c|c|c|c|c|c|}
\hline $\begin{array}{l}\text { Population of } \\
\text { reference } \\
\text { Country }\end{array}$ & $\begin{array}{c}\text { Total } \\
\text { married } \\
\text { population }\end{array}$ & $\begin{array}{c}\text { Married } \\
\text { native-born } \\
\text { men } \\
\end{array}$ & $\begin{array}{c}\text { Married } \\
\text { native-born } \\
\text { women } \\
\end{array}$ & $\begin{array}{c}\text { Married } \\
\text { foreign-born } \\
\text { men } \\
\end{array}$ & $\begin{array}{c}\text { Married } \\
\text { foreign-born } \\
\text { women }\end{array}$ \\
\hline Belgium & 11.0 & 6.7 & 6.2 & 35.8 & 37.8 \\
\hline Bulgaria & 0.4 & 0.3 & 0.2 & 76.8 & 85.9 \\
\hline Czech Republic & 4.0 & 2.0 & 2.1 & 64.0 & 64.3 \\
\hline Denmark & 6.8 & 4.4 & 2.9 & 44.6 & 55.1 \\
\hline Germany & 11.2 & 6.8 & 6.8 & 28.4 & 28.6 \\
\hline Estonia & 15.8 & 9.5 & 11.1 & 36.6 & 30.3 \\
\hline Ireland & 11.6 & 6.8 & 6.6 & 37.7 & 38.3 \\
\hline Greece & 3.0 & 2.4 & 0.8 & 9.8 & 25.3 \\
\hline Spain & 5.4 & 3.6 & 2.6 & 18.2 & 23.5 \\
\hline France & 11.8 & 6.6 & 7.3 & 38.8 & 36.7 \\
\hline Italy & 5.1 & 3.7 & 1.8 & 23.4 & 39.2 \\
\hline Cyprus & 12.4 & 10.0 & 4.7 & 28.0 & 44.5 \\
\hline Latvia & 20.7 & 12.5 & 13.7 & 50.4 & 48.0 \\
\hline Lithuania & 6.1 & 3.0 & 3.5 & 59.0 & 55.0 \\
\hline Luxembourg & 18.2 & 18.0 & 13.7 & 18.2 & 23.8 \\
\hline Hungary & 2.2 & 1.3 & 1.0 & 44.1 & 51.8 \\
\hline Malta & 7.6 & 4.4 & 3.6 & 69.6 & 73.9 \\
\hline Netherlands & 9.3 & 5.8 & 4.7 & 37.1 & 42.1 \\
\hline Austria & 10.8 & 7.9 & 5.4 & 23.6 & 31.5 \\
\hline Poland & 1.3 & 0.5 & 0.7 & 73.4 & 66.7 \\
\hline Portugal & 7.0 & 4.3 & 3.3 & 45.3 & 51.6 \\
\hline Romania & 0.1 & 0.0 & 0.1 & 57.5 & 42.8 \\
\hline Slovenia & 8.9 & 4.6 & 5.5 & 39.4 & 34.8 \\
\hline Slovakia & 1.9 & 1.0 & 0.9 & 87.4 & 88.1 \\
\hline Finland & 3.6 & 2.0 & 1.7 & 48.2 & 53.0 \\
\hline Sweden & 9.3 & 6.2 & 4.5 & 29.7 & 37.7 \\
\hline United Kingdom & 8.8 & 5.7 & 4.4 & 28.1 & 34.0 \\
\hline Iceland & 7.2 & 4.6 & 3.1 & 54.6 & 64.6 \\
\hline Norway & 8.6 & 5.6 & 3.7 & 48.0 & 58.3 \\
\hline Switzerland & 21.0 & 15.5 & 11.7 & 35.5 & 41.2 \\
\hline Average & 8.4 & 5.5 & 4.6 & 43.0 & 46.9 \\
\hline
\end{tabular}




\section{Mixed marriages as factors of socio-cultural change}

Persons in mixed marriages may contribute directly and indirectly to shaping the social and cultural profile of the host population. They themselves cross boundaries between groups, and their descendants are less likely to identify with a single group. Their networks may also gain better knowledge of other group(s), weakening stereotypes.

The extent of the presence of these actors in the host population is estimated in Table 2. In the total population, on average across Europe, one person out of 25 of marriageable age brings this potential change. Within each specific subgroup, the proportions are different and are more relevant among foreign-born persons, where sex differentials are also more significant. On average, one foreign-born person out of four of marriageable age is in a mixed marriage. These potential carriers of socio-cultural change are the cumulative result of past migrations and demographic dynamics, and may not be representative of single communities or changing migration patterns (e.g. future immigration flows from new sending countries).

Those percentages also depend on the relevance of the institution of marriage, which is differently perceived across Europe. In several countries, alternative forms of consensual union are a reality nowadays. Although they could be considered as crossing looser boundaries than marriages, the significance of these potential socio-cultural forces may be greater than is estimated here, possibly by several percentage points. More uncertain is the role of those who were previously in a mixed marriage, but are divorced at the time of the survey, as their experience may have the opposite influence.

Table 2: average 2008-10 of the percentage of persons in mixed marriage by country and population of reference of marriageable age

\begin{tabular}{|c|c|c|c|c|c|}
\hline $\begin{array}{l}\text { Population of } \\
\text { reference } \\
\text { Country } \\
\end{array}$ & $\begin{array}{c}\text { Total } \\
\text { population } \\
\text { of marr. age }\end{array}$ & $\begin{array}{c}\text { Native-born } \\
\text { men } \\
\text { of marr. age }\end{array}$ & $\begin{array}{c}\text { Native-born } \\
\text { women } \\
\text { of marr. age }\end{array}$ & $\begin{array}{c}\text { Foreign-born } \\
\text { men } \\
\text { of marr. age }\end{array}$ & $\begin{array}{c}\text { Foreign-born } \\
\text { women } \\
\text { of marr. age }\end{array}$ \\
\hline Belgium & 5.2 & 3.3 & 2.8 & 19.6 & 18.0 \\
\hline Bulgaria & 0.2 & 0.1 & 0.1 & 33.5 & 42.5 \\
\hline Czech Republic & 2.1 & 1.1 & 1.0 & 37.1 & 33.4 \\
\hline Denmark & 3.2 & 2.1 & 1.3 & 21.0 & 28.2 \\
\hline Germany & 5.8 & 3.5 & 3.3 & 18.7 & 17.1 \\
\hline Estonia & 6.3 & 3.8 & 3.7 & 26.2 & 13.8 \\
\hline Ireland & 5.6 & 3.4 & 3.1 & 17.5 & 18.0 \\
\hline Greece & 1.8 & 1.5 & 0.5 & 5.3 & 16.4 \\
\hline Spain & 3.0 & 2.1 & 1.4 & 8.8 & 11.5 \\
\hline France & 5.6 & 3.2 & 3.2 & 24.7 & 20.5 \\
\hline Italy & 2.8 & 2.2 & 1.0 & 12.1 & 21.9 \\
\hline Cyprus & 7.6 & 6.9 & 2.8 & 14.6 & 21.5 \\
\hline Latvia & 8.3 & 5.2 & 4.7 & 34.8 & 20.3 \\
\hline Lithuania & 3.0 & 1.5 & 1.5 & 41.4 & 25.2 \\
\hline Luxembourg & 10.0 & 9.4 & 6.5 & 11.4 & 14.9 \\
\hline Hungary & 1.1 & 0.7 & 0.4 & 27.4 & 27.4 \\
\hline Malta & 4.3 & 2.5 & 2.0 & 42.8 & 47.1 \\
\hline Netherlands & 4.8 & 3.0 & 2.4 & 19.5 & 21.4 \\
\hline Austria & 5.3 & 3.9 & 2.5 & 14.0 & 18.1 \\
\hline Poland & 0.7 & 0.3 & 0.4 & 53.6 & 26.6 \\
\hline Portugal & 4.4 & 2.8 & 2.0 & 28.8 & 32.2 \\
\hline Romania & 0.1 & 0.0 & 0.0 & 36.9 & 29.0 \\
\hline Slovenia & 4.3 & 2.2 & 2.5 & 26.1 & 23.1 \\
\hline Slovakia & 1.0 & 0.5 & 0.5 & 61.9 & 54.7 \\
\hline Finland & 1.7 & 1.0 & 0.8 & 24.9 & 27.8 \\
\hline Sweden & 4.0 & 2.7 & 1.9 & 14.5 & 18.7 \\
\hline United Kingdom & 4.2 & 2.9 & 2.0 & 15.3 & 17.3 \\
\hline Iceland & 3.2 & 2.1 & 1.4 & 23.3 & 32.3 \\
\hline Norway & 3.9 & 2.6 & 1.7 & 21.2 & 31.0 \\
\hline Switzerland & 10.5 & 7.8 & 5.4 & 20.1 & 22.7 \\
\hline Average & 4.1 & 2.8 & 2.1 & 25.2 & 25.1 \\
\hline
\end{tabular}




\title{
METHODOLOGICAL NOTES
}

The estimates are produced using data primarily from the Labour Force Survey (LFS), supplemented with data from the Survey on Income and Living Conditions (SILC). The population of reference in LFS and SILC (persons living in private households aged 15-16 years and more) is here considered as an estimate of the population of marriageable age (persons capable of contracting a marriage in virtue of their age). The minimum age at marriage and its exceptions are laid down by law; they may differ from country to country and may be different for the two sexes. Persons in mixed marriage are those legally married native-born persons living with a legally married foreign-born partner (same or opposite sex) in private households (and vice versa).

The countries included in this study are the 27 Member States of the EU plus 3 countries member of the European Free Trade Association (EFTA): Belgium (BE), Bulgaria (BG), the Czech Republic (CZ), Denmark (DK), Germany (DE), Estonia (EE), Ireland (IE), Greece (EL), Spain (ES), France (FR), Italy (IT), Cyprus (CY), Latvia (LV), Lithuania (LT), Luxembourg (LU), Hungary (HU), Malta (MT), the Netherlands (NL), Austria (AT), Poland (PL), Portugal (PT), Romania (RO), Slovenia (SI), Slovakia (SK), Finland (FI), Sweden (SE), the United Kingdom (UK), Iceland (IS), Norway (NO) and Switzerland (CH).

Data are not available for Switzerland 2005-2007 and for Bulgaria 2005.

All statistics presented in this report are experimental and are not part of the regular production of Eurostat. Their sources are calculations of the author from LFS and SILC data.

\section{Further information}

Eurostat Website: http://ec.europa.eu/eurostat

\author{
Journalists can contact the media support service: \\ Bech Building, Office A4/125, L-2920 Luxembourg \\ Tel.: (352) 430133408 \\ Fax: (352) 430135349 \\ E-mail: eurostat-mediasupport@ec.europa.eu
}

\section{European Statistical Data Support:}

With the members of the 'European statistical system', Eurostat has set up a network of support centres in nearly every Member State and in some EFTA countries.

Their role is to provide help and guidance to Internet users of European statistics.

Contact details for this support network can be found on the Eurostat website at: http://ec.europa.eu/eurostat/.

All Eurostat publications can be ordered via the 'EU Bookshop':

http://bookshop.europa.eu/. 